\title{
CONVERGÊNCIAS ENTRE O SUBLIME E 0 GROTESCO NA ARTE ROMÂNTICA
}

\section{CONVERGENCES BETWEEN THE SUBLIME AND THE GROTESQUE IN ROMANTIC ART}

Milla Bioni Guerra 


\section{Resumo}

Esta pesquisa tem como objetivo o esclarecimento acerca dos conceitos do Sublime e do Grotesco segundo o período histórico denominado Romântico, e das correlações entre eles. A pesquisa se fundamenta nos pensamentos de Edmund Burke, Friedrich Schiller e Victor Hugo, os quais fazem parte do momento artístico escolhido e abordam o tema de maneira abrangente e profunda.

Palavras-chave: Sublime; Grotesco; História da Arte; Romantismo; Estética.

\section{Abstract}

The aim of the present study is to enlight the concepts " The Sublime and The Grotesque" according to the historic period called Romantic, and correlations between them. These research is based on the philosophy of Edmund Burk, Friedrich Schiller and Victor Hugo, who were deeply involved in the historical moment and approached the theme thoroughly.

Keywords: Sublime, Grotesque, Art History, Romantic Period, Aesthetic.

ISSN: 2175-2346 


\section{Introdução}

Os conceitos de estética do Sublime e do Grotesco já eram conhecidos na antiguidade, entretanto receberam mais ênfase no contexto da literatura. Assim, no século I pseudo-Longino aborda o sublime referindo-se a características do discurso da linguagem. Já o grotesco deriva de estilos de ornamentação e mais tarde se volta para a prática literária.

o grotesco ocorre em uma ampla prática artística que extrai de uma pintura ornamental romana, descoberta em fins do século XV, a qual foi denominada de grotesca, derivação do substantivo italiano grotta (gruta). (VÁZQUEZ, 1999, p. 285)

Entretanto, no romantismo estas duas formas de relacionar-se com a arte se dão de maneira particular. O Sublime a partir do romantismo é visto nas forças poderosas da natureza, o Sublime é uma mescla de assombro, horror e deleite. Já o Grotesco inunda cada canto da fantasia do artista, desvenda a própria natureza sombria do homem e a coloca nas infinitas representações do macabro, monstruoso e sombrio.

De que maneira o homem do romantismo se relacionava com a natureza e consigo mesmo, a fim de que o Sublime e o Grotesco se desenvolvessem na arte de maneira tão predominante? E em que âmbitos essas duas categorias estéticas se relacionam e convergem?

O presente trabalho trata de averiguar a maneira como o homem do romantismo concebia essas duas formas de estética e como estas se manifestavam na arte. Para isto, será utilizado o pensamento de Edmund Burke (1729 - 1797), o qual entende que, para se chegar a uma reflexão mais exata do Sublime é necessário averiguar as paixões e emoções no homem que são os motores para o surgimento deste sentimento. Em seguida, Burke descreve as qualidades na natureza que são necessárias para que se possa vivenciar o deleite causado pelo Sublime.

Não seguindo por caminho tão distante, Johann Christoph Friedrich von Schiller (1759 - 1805), se preocupa com uma utilidade moral no seu estudo sobre o sublime, assim aborda o tema levando em conta a liberdade da razão do homem ao se relacionar com as forças da natureza.

A seguir será abordada a estética do grotesco. Para a estruturação do conceito do grotesco será utilizado o pensamento do poeta Victor-Marie Hugo (1802 -1885).

Para esse, o Grotesco relaciona-se na arte com a parte sombria do homem, com os seus vícios, suas paixões. É a partir do grotesco que nascem a comédia e a sátira.

Para encerrar a pesquisa serão integradas essas duas estéticas. Como no romantismo, o Sublime e o Grotesco se configuravam paralelamente, não apenas na arte, mas na forma como o homem via a si mesmo e como esse se relacionava com o mundo.

\section{A estética do sublime}

Sublime foi um conceito já explorado pelos antigos como um termo literário, referente a um êxtase e transcendência que a obra literária causaria ao leitor. A primeira fonte que discorre sobre este tema é o tratado do Sublime atribuído a 
Pseudo-Longino (213-273 d.C.). O qual define de forma poética: "sublime é o eco da grandeza de alma."

O termo sublime etimologicamente deriva do latim sublimis, composto de sub-limen. De sub, "abaixo", e limen, o que está suspenso na arquitrave da porta (lat. Limes), o lintel entre duas colunas (O.E.D). Tendo como significado metafórico algo que está acima do homem, ou está abaixo contemplando algo superior.

Na perspectiva setecentista, a ideia do Sublime associa-se antes de tudo a uma experiência não concernente à arte, mas a natureza, e nesta experiência são privilegiados o informe, o doloroso e o tremendo. (ECO, 2004, p. 281)

Mais tarde, a partir do século XVIII, os românticos retomam este tema ressignificando e aprofundando este conceito.

No século XVIII, ao contrário, o universo do prazer estético divide-se em duas províncias, a do Belo e a do Sublime, embora as duas províncias não se apresentem totalmente separadas (...) Pois a experiência do Sublime adquire muitas daquelas características atribuídas anteriormente à experiência do Belo. (ECO, 2004, p. 282)

O escritor irlandês Edmund Burke, conhecido principalmente como autor de Reflexões sobre a revolução em França (1790), entra no campo da estética com o tratado Uma investigação filosófica sobre a origem de nossas ideias do sublime e do belo [A Philosophical Inquiry into the Origin of Our Ideas of the Sublime and Beautiful], 1757 e 1759, o qual resultou em um dos mais importantes tratados do seu tempo, que mais tarde viria a inspirar Kant para a elaboração dos conceitos do sublime no seu livro Crítica da faculdade do juízo, 1790.

Burke trata, antes de definir o Sublime, de reconhecer no homem os motores dentro das nossas sensações e paixões aquelas que seriam capazes de incitar o sublime. Desta maneira, para compreender o sublime recorre não apenas a uma descrição de qualidades dos elementos exteriores que despertam essa emoção, mas também uma investigação exata e atenta às paixões humanas.

O autor considera que para mover as paixões em um grau considerável, além de um grau de curiosidade, ao que ele coloca como uma emoção elementar no espírito do homem e como um desejo qualquer pela novidade, faz-se necessário que se incite a dor ou o prazer.

Entre estas duas identifica que a dor está mais ligada ao sentimento do sublime do que o prazer, posto que a dor quando cessa causa uma impressão mais forte no espírito do homem, um misto de serenidade e espanto.

Esse estado da alma que surge com e atenuação ou eliminação da dor não seria de forma alguma o mesmo que o prazer, e Burke chama este "prazer relativo" que surge com a atenuação da dor de Deleite.

O deleite desta maneira é a base da experiência do Sublime, como forma de catarse "Assim como empregarei a palavra deleite para indicar a sensação que acompanha a eliminação da dor ou do perigo; portanto, quando me referir ao prazer positivo, chamá-lo-ei, na maioria das vezes, simplesmente de prazer." (BURKE, 1993, p. 46). 
Burke colocará as emoções referentes à autopreservação do indivíduo como capazes de produzir uma forte impressão no espírito pois derivam da dor e do perigo. A experiência da autopreservação afeta diretamente 0 indivíduo e pode causar 0 sublime na medida em que somos capazes de viver a experiência da dor e do perigo apenas como ideia. Chega-se então a uma definição mais objetiva do sublime:

Tudo que seja de algum modo capaz de incitar as ideias de dor e de perigo, isto é, tudo que seja de alguma maneira terrível ou relacionado a objetos terríveis ou atua de um modo análogo ao terror constitui uma fonte do sublime, isto é, produz a mais forte emoção de que o espírito é capaz. (BURKE, 1993, p. 48)

As tempestades representam no romantismo um forte impulso para a vivência do Sublime ligado ao perigo e à dor que os poderes da natureza podem causar no homem. A figura 1 mostra um navio sendo ameaçado por uma tempestade no mar, o perigo do navio afundar é obviamente eminente, entretanto a obra carrega certo grau de tranquilidade, o fato se deve provavelmente a utilização predominante das cores cinza, e as gaivotas voando calmamente no céu trazem um resquício de esperança.

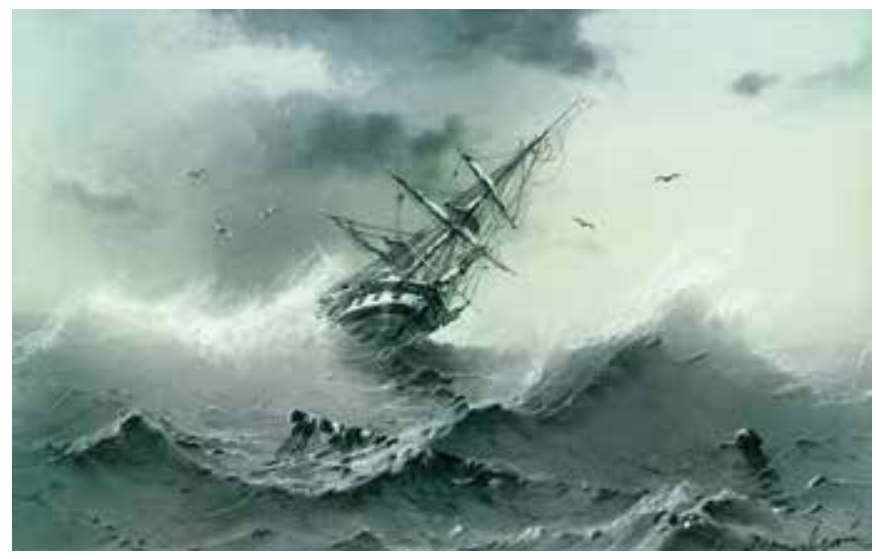

Fig. 1 - Ivan Aivazovsky, Navio Naufragado, 1854. Guache sobre papel. Fonte: www.wikiart.org

Da mesma maneira que se investigaram as paixões básicas capazes de incitar o espírito de maneira intensa, Burke passa a olhar para as qualidades necessárias dos objetos capazes de levarem ao sublime. Inicia-se com a mais elementar, o assombro:

A paixão a que o grandioso e sublime na natureza dá origem, quando essas causas atuam de maneira mais intensa, é o assombro, que consiste no estado de alma no qual todos os seus movimentos são sustados por um certo grau de horror. (BURKE, 1993, p. 65)

A partir do assombro - como origem do poder do sublime - desenrola-se uma série de emoções que podem ser desencadeadas a partir daí. "O assombro, como disse, é o efeito do sublime em seu mais alto grau; os efeitos secundários são a admiração, a reverência e o respeito." (BURKE, 1993, p. 65)

O grandioso na natureza se encontra em quase toda parte. Nas obras de arte no romantismo o ser humano muitas vezes é colocado de forma diminuída frente à grandiosidade da natureza. A diminuição do homem não está apenas na forma 
de representá-lo mas na sensação que a atmosfera de imponência e abundância transmite. O sentimento de assombro é quase que inevitável, e em conjunto com a forte tendência religiosa dos românticos não há como não sucumbir a uma admiração e respeito frente ao enorme poder que se mostra. Na figura 2, o homem no canto inferior esquerdo é quase que imperceptível pelo seu minúsculo tamanho, servindo apenas como referência de escala para o observador da obra sentir o monumental tamanho das montanhas e impotência humana frente a natureza.

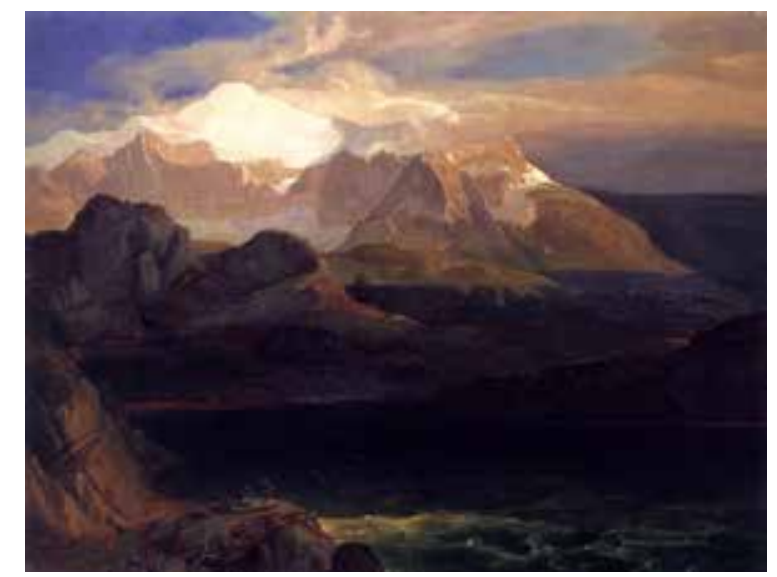

Fig. 2 - Carl Rottmann, Vista de Eibsee, 1825. óleo sobre tela, 98 x $76 \mathrm{~cm}$; Nova Pinacoteca, Munique. Fonte: www.reproarte.com

O terror, de forma clara desperta assombro na alma do homem, visto que este pode vir a causar dor ou até mesmo a morte.

Nenhuma paixão despoja tão completamente o espírito de toda as sua faculdade de agir e de raciocinar quanto o medo. Pois este, sendo um pressentimento de dor ou de morte, atua de maneira semelhante à dor real. Portanto, tudo que é terrível à visão é igualmente sublime, quer essa causa de terror seja dotada de grandes dimensões ou não, pois é impossível considerar algo que possa ser perigoso como insignificante ou desprezível. (BURKE, 1993, p. 65 - 66)

Todo Sublime gera uma modificação em relação ao poder, pois o poder de maneira alguma nos deixa em estado de neutralidade. Tudo aquilo que tem o poder de submeter a ideia de dor ou de morte será uma fonte de terror. "Mas a dor é sempre infligida por um poder de certo modo superior, porque nunca nos submetemos voluntariamente a ela." (BURKE, 1993, p. 72)

Desta forma, o poder sendo entendido como uma força que se impõe como algo superior e indomável é considerado sublime, já as forças que estão a serviço de algo utilitário ou inferior não podem ser consideradas poder, pois não acarretam nenhum tipo de espanto ou terror e desta forma não são sublimes. "Em suma, onde quer que encontremos a força e sob qualquer ângulo do que consideramos o poder, veneramos sempre o sublime acompanhado do terror e do desprezo ligado à força submissa e inofensiva." (BURKE, 1993, p.73) (ver fig. 25 e 26)

Além do poder, as privações são capazes de promover o sublime, pois com estas o homem é capaz de se deparar com uma forte ideia de dor. "Todas as privações em geral são grandiosas, porque são todas terriveis: vazio, trevas, solidão e silêncio." 
(BURKE, 1993, p. 76)

As privações que Burke cita são as que o homem romântico se deparava no seu momento histórico. A solidão é uma forma de sacrifício para poder estar em contato com elementos superiores, a contemplação da natureza requeria uma forma de solidão para poder alcançar uma forma de meditação religiosa. Neste processo, o silêncio também é um elemento indispensável, sendo este parte integrante da solidão.

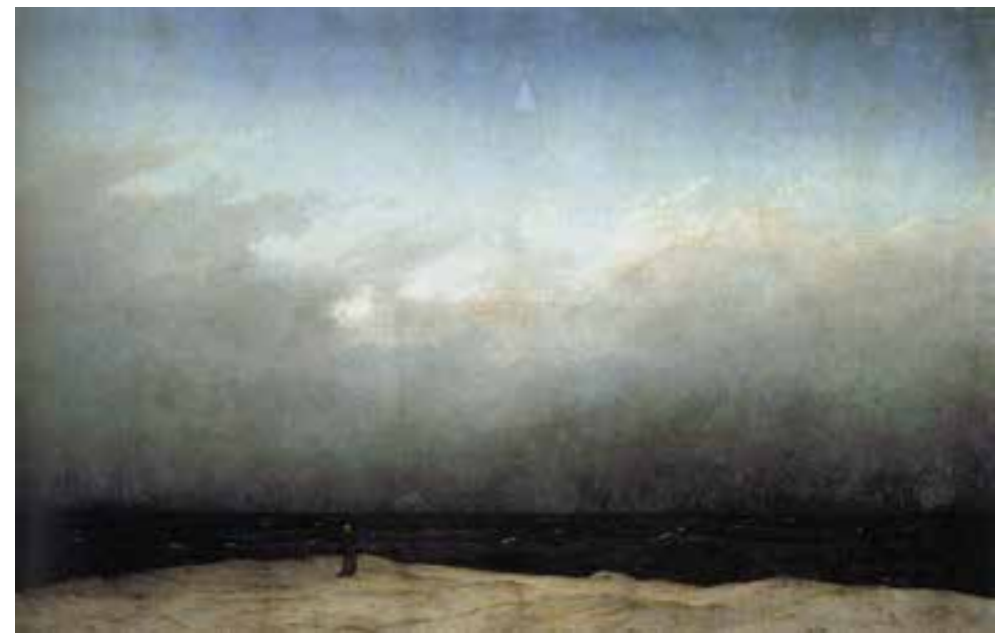

Fig. 3 - Caspar Friedrich, O monge a Beira Mar, 1809 - 1810. Óleo sobre tela, 110 x 171,5 cm; Nationalgalerie, Staatliche Museen, Berlim.

Fonte: www.wikiart.org

A figura 3 é uma importante representação do Sublime, tanto pela maneira como foi pintada como pela forte representação do homem à mercê dos poderes da natureza.

A amplitude do céu, que se estende para além da tela, é repleta de forças celestes. As pinceladas fortes trazem uma indefinição entre o mar, as nuvens e o céu criando uma impressionante atmosfera carregada de forças poderosas. Friedrich expressa nesta obra a tão necessária solidão para estar integrado as forças invisíveis da natureza, assim também comenta: "Devo render-me ao que me cerca, unindo-me eu próprio às nuvens, e as rochas, a fim de ser o que sou. Preciso da solidão a fim de me comunicar com a natureza". (FRIEDRICH apud WOLF , 2008, p. 10)

O homem esguio está só, isolado da sociedade, vivencia uma imensa solidão e silêncio, levando-o a conectar-se ao movimento interno que acontece na natureza. É uma relação do homem com os motores invisíveis destas forças, ou seja, a divindade. "A solidão absoluta e integral, ou seja, exclusão total e perpétua de toda sociedade é uma dor positiva tão intensa quanto se possa imaginar." (BURKE, 1993, p. 51)

Nada pode ser mais grandioso que a ideia do poder provindo de Deus. Os românticos consideravam a ideia de Deus como poder proveniente da natureza. Desta maneira ao olhar para o mundo sensível o homem romântico se depara com a sua ideia da divindade.

Ao retratar a fúria de um mar em tempestade, a imponência do cume da montanha, a grandiosidade do pôr do sol sobre o mar, a serenidade e o mistério da bruma sobre os rochedos; trata-se de um ato de devoção, reverência e admiração perante um poder maior. 


\begin{abstract}
Mas quando contemplamos um objeto tão incomensurável, sob a força, por assim dizer, do poder absoluto, e totalmente envolvidos por sua onipresença, recolhemo-nos à insignificância de nossa própria natureza e somos como que anulados perante ele. E, embora a consideração de seus outros atributos possa até certo ponto abrandar nossos temores, ainda assim nenhuma certeza da justiça com que ela se exerce, nem da misericórdia pela qual é suavizada pode afastar completamente o terror que nasce naturalmente de uma força que nada pode deter. (BURKE, 1993, p. 74)
\end{abstract}

Vistas as paixões que o sublime incita no homem, resta dedicar-se a perceber no exterior os elementos que são, por própria natureza, promotores da experiência do sublime.

"A grandiosidade de dimensões é uma fonte poderosa do sublime." (BURKE, 1993, p. 77) O imensamente grande e o que se esvai ao incalculavelmente pequeno foge aos sentidos do homem e escapa à imaginação, tornando-se um elemento que causa assombro e deixa atônita a alma do homem. Ou seja, o que foge a percepção dos sentidos e se torna incapaz de medir a sua totalidade ou sua divisão que parece ser infinita, torna-se uma fonte do sublime.

Pela própria limitação do homem para perceber o limite de certos objetos, a imaginação os estende e os torna incomensuráveis, gerando uma ideia de infinitude.

$\mathrm{Na}$ arquitetura também se encontra certo tipo de infinitude. A arquitetura quando possui determinadas qualidades, como a grandiosidade, visto que o homem é reduzido frente a uma gigantesca estrutura, pode levar ao sentimento do sublime. $\mathrm{Na}$ figura 4, percebe-se o homem no canto inferior esquerdo, inofensivo e solitário entre as imensas colunas. A luz entra por alguma abertura e deixa o ambiente banhado por uma calma e serenidade contemplativa.

A luz e a cor são elementos importantes a se observar, principalmente no que se refere à pintura. A luz deve causar uma impressão forte para promover o sublime, visto que em circunstâncias normais ela é comum demais.

Todas as cores dependem da luz. Esta, portanto, deve ser examinada em primeiro lugar e, com ela, seu oposto, as trevas. Com relação à luz: para torná-la capaz de gerar o sublime, ela deve ser acompanhada de algumas circunstâncias, além de sua mera faculdade de mostrar os objetos. (BURKE, 1993, p. 86) 


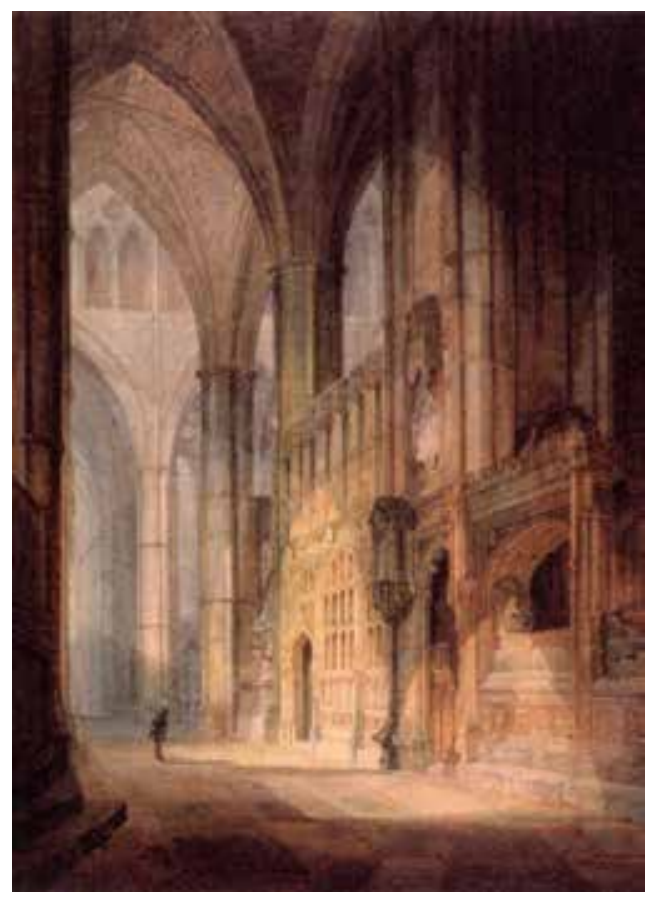

Fig. 4 - William Turner, Santo Erasmus Na Capela Bishop Islips - Abadia De Westminster, 1796. Aquarela e grafite sobre papel, 54,6 × 39,8 cm; British Museum, Londres, Inglaterra.

Fonte: www.wikiart.org

Desta maneira, Burke levanta uma série de condições necessárias para que a luz ou a cor causem uma impressão de assombro no espírito.

Uma luz que tenha capacidade de aturdir os sentidos, como quando se olha diretamente para o sol, esta pode causar uma impressão de grandiosidade e poder.

As polaridades apresentadas ao mesmo tempo e de maneira intensa, como entre luz e trevas também leva à sensação do Sublime. "Uma transição brusca da luz para as trevas, ou destas para a luz, causa um efeito ainda maior." (BURKE, 1993, p. 86)

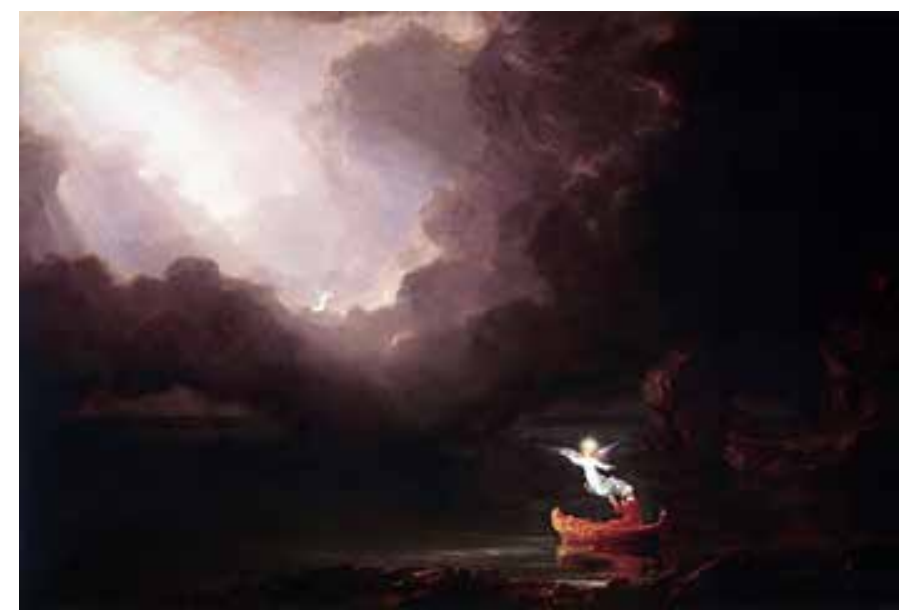

Fig. 5 - Thomas Cole, As Idades da Vida: Velhice, 1842. Óleo sobre tela, 133,4 x 196,2 cm; Brooklyn Museum, Brooklyn, Nova York.

Fonte: www.wikiart.org

$\mathrm{Na}$ figura 5, a representação da polaridade se mostra de maneira intensa, no canto superior esquerdo a luz irradia do alto simbolizando a luz que provém de algo superior, ligado a elementos superiores no homem. A luz se confronta com as trevas, 
a qual causa uma forte impressão. De maneira metafórica, pode-se considerar esta imagem como a representação do confronto do homem entre suas duas naturezas, uma terrestre e outra celeste.

Mas, a luz mesmo nestas circunstâncias não gera o mesmo efeito que as trevas, pois as trevas carregam a ideia do terror e do desconhecido. "Mas as trevas são mais fecundas de ideias sublimes do que a luz." (BURKE, 1993, p. 86)

Há, porém uma qualidade na luz que muito se assemelha à ideia da obscuridade e esta pode ser comparada à ideia de Sublime que as trevas proporcionam. "A luz excessiva, ao ofuscar a vista, oblitera todos os objetos, fazendo com que seu efeito se assemelhe exatamente ao das trevas." (BURKE, 1993, p. 87).

No seu extremo, estas duas polaridades chegam ao mesmo efeito. Os extremos, o absurdo e o imenso são qualidades notórias do Sublime, pois este sentimento foge da normalidade e do insignificante.

Burke coloca uma das principais ideias do Sublime: a atividade do homem em querer preservar a sua existência é um instinto básico, a autopreservação surge quando determinada força ameaça a existência do homem, ou seja, coloca o homem em uma situação na qual é diminuído fisicamente, uma força com maior potência o subjuga, o torna inferior. Surge, então, certo tipo de assombro, um sentimento que move a alma em direção a uma admiração a esse poder que se impõe sobre ele.

Quando Burke descreve as ideias de Sublime provenientes dos sentidos, percebem-se algumas ideias muito semelhantes àquelas que são atribuídas ao Grotesco, este como causador do terror e do medo: "Sons como os que imitam a voz natural e inarticulada do homem ou de qualquer outro animal sob a ação da dor ou do perigo têm o poder de suscitar ideias grandiosas, (...)" (BURKE, 1993, p. 90).

Estas impressões tornam-se interessantes porque instigam a imaginação, fazem com que se criem imagens terríveis ou atmosferas de mistério. Para Burke, o conceito de Sublime é aquilo que leva a alma a um intenso movimento. Desta maneira as experiências sensoriais que possibilitam que o homem se sinta desamparado no sentido físico, desprotegido e em perigo, despertam o sentimento do sublime, pois o homem é instigado internamente e a sua imaginação é desafiada.

"Mas, uma luz que ora surge, ora desaparece, apagando e acendendo-se, é ainda mais terrível do que a escuridão total, (...)" (BURKE, 1993, p. 90)

Como já mencionado, a origem desconhecida de certos fenômenos leva a ser incitada a imaginação, e esta é capaz de fantasiar macabros e terriveis motivos para o surgimento destes fenômenos. As histórias de espíritos e de criaturas fantásticas tornam-se muito populares no romantismo, além das obras de Shakespeare as quais, muitas são constituídas por situações similares, como é o caso de Hamlet que se encontra com o espírito do seu falecido pai, que the traz revelações acerca de seu assassino.

Perante o conceito que Burke levantou acerca do sublime como promotor de um sentimento forte e intenso, as ideias do grotesco não estariam muito distantes do Sublime. Pode-se pensar neste âmbito o Grotesco como um dos elementos que podem incitar o Sublime, não como transcendência de uma relação de devoção ao divino, mas no sentido contrário a algo que se relaciona diretamente com o nosso sentimento de autopreservação, terror, assombro e medo. 
Isto pode ficar mais evidente quando suas descrições em muito se assemelham a alguns elementos presentes nas histórias de terror, cada vez mais populares no romantismo:

Já observei que a noite aumenta nosso terror talvez mais do que qualquer outra coisa; é próprio de nossa natureza, quando não sabemos o que nos pode acontecer, recear o pior, e por esse motivo a incerteza é tão terrível que, muitas vezes, procuramos dela nos livrar até mesmo ao preço de um mal inevitável. (BURKE, 1993, p. 90)

A figura 6 mostra o intenso efeito da noite sobre a alma e incita uma atmosfera de perigo, de mistério e do desconhecido. A luz que provém da lua é parcialmente encoberta por nuvens, surpreendentemente causa uma impressão de serenidade e tranquilidade, mas ao mesmo tempo uma certa tensão e respeito pela qualidade da noite.

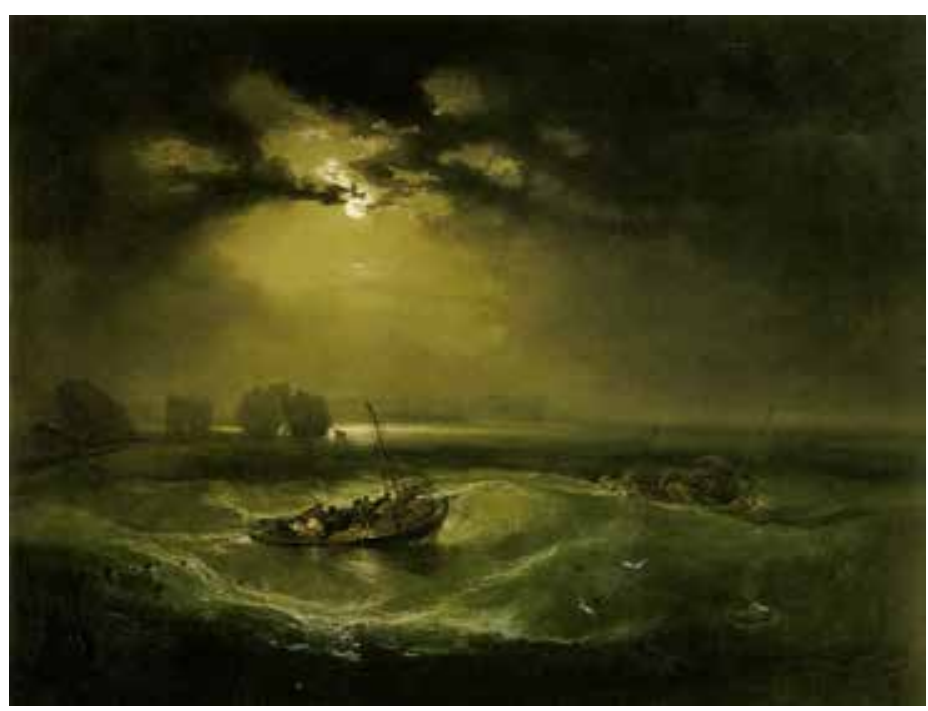

Fig. 6 - Willian Turner, Pescadores e o mar, 1796. óleo sobre tela, $91 \times 122 \mathrm{~cm}$; Tate Gallery, Londres. Fonte: www.wikiart.org

Friedrich Schiller pela influência de seus estudos da Crítica a faculdade do juízo de Imannuel Kant também se dedica a refletir sobre as ideias do Sublime, porém reelabora esse tema propondo novas ideias de se relacionar com o Sublime.

Essas reflexões renderam uma série de artigos publicados em dois periódicos durante a década de 1790. Os artigos que serão analisados aqui foram publicados entre 1792 e 1793, e são eles Do Sublime (por uma exposição ulterior de algumas ideias kantianas) de 1792, e Sobre o Sublime.

Embora as ideias de Burke não divirjam com as elaboradas por Schiller, este último vai mais além ao que se refere à atividade interna do homem frente ao objeto do sublime. Tem a preocupação de refletir sobre a liberdade moral.

Schiller elabora desta forma o conceito do Sublime:

Sublime denominamos um objeto frente a cuja representação nossa natureza sente suas limitações, enquanto nossa natureza racional sente sua superioridade, sua liberdade de limitações; portanto, um objeto contra o qual levamos a pior fisicamente, mas sobre o qual elevamos moralmente, i. e., por meio de ideias. (SCHILLER, 2011, p. 21) 
Da mesma forma que Burke relaciona o sublime com objetos que escapam ao controle do homem, que por possuir tamanha grandeza se sente diminuído a um poder que não pode compreender, Schiller mantém esse pensamento, entretanto insere a participação ativa do homem com a escolha da liberdade moral, com a qual o homem é capaz de elevar-se frente às forças da natureza diante das quais fisicamente encontra-se diminuído e pode sofrer danos.

"Somos dependentes apenas enquanto seres sensiveis; enquanto seres racionais, somos livres." (SCHILLER, 2011, p. 21) Talvez estas palavras sejam as que melhor exprimem os pensamentos de Schiller referentes ao Sublime, pois é justamente essa elevação racional frente ao perigo eminente que permite experienciar o Sublime.

O Sublime, em primeiro lugar, faz com que frente às forças que o homem não pode conter sinta sua dependência como ser natural, e em segundo lugar seja capaz de manter sua independência como ser racional.

Enquanto seres sensíveis, o homem possui dois impulsos fundamentais dos quais derivam todos os outros, os quais Schiller assim os classifica:

Em primeiro lugar, possuímos um impulso de alterar nosso estado, de exprimir nossa existência, de ser atuantes, e tudo isso equivale a adquirir representações; desse modo, pode-se chama-lo impulso de representação, impulso de conhecimento.

Em segundo lugar, possuímos um impulso de conservar nosso estado, de levar adiante nossa existência, o qual se denomina o impulso de autoconservação. (SCHILLER, 2011, p. 22)

Esses dois impulsos como seres sensíveis fazem com que o homem permaneça dependente a natureza de duas formas: "O impulso de representação remete a conhecimento, o de autoconservação a sentimentos, portanto, a percepções internas da existência." (SCHILLER, 2011, p. 22).

Estas dependências são percebidas no homem na medida em que a natureza o põe em contato com aquilo que o torne carente em algum sentido. Uma destas dependências é a falta de condições para atingir o conhecimento, e a outra, situações que levam a por em risco a existência.

Já a independência do homem que vai contra as dependências acima nomeadas se dão da seguinte maneira:

Do mesmo modo, mantemos por meio da nossa razão uma dupla independência da natureza: em primeiro lugar, na medida em que podemos ultrapassar as condições naturais (no que é teórico) e no pensar mais do que conhecemos; em segundo lugar, na medida em que podemos passar por cima das condições naturais ( no que é prático) e contradizer nosso apetite através de nossa vontade. Um objeto frente a cuja percepção experimentamos a primeira independência é grande de modo teórico, um sublime do conhecimento. Um objeto que nos faz sentir a independência de nossa vontade é grande de modo prático, um sublime do modo de pensar. (SCHILLER, 2011, p. 23)

Assim Schiller, apropriando-se dos conceitos já elaborados por Kant de Sublime matemático e Sublime dinâmico, reelabora estes dois tipos de Sublime: 
contradição com o impulso de representação. No sublime prático, ela se encontra, enquanto objeto da sensação, em contradição com o impulso de conservação. (SCHILLER, 2011, p.23)

Quando a natureza põe o homem em um estado que ameace sua vida física, que põe em risco a sua existência, a natureza o mantém dependente. Para manter em vista essa relação com a natureza, o homem encontra impulso de autoconservação, que o mantém atento.

Assim, conforme Schiller, o Sublime prático é vivenciado quando o homem supera de forma moral os perigos que ameaçam a sua existência.

Mas, mesmo frente ao perigo eminente, aquele que causa temor e que pode levar à dor e ao sofrimento, o homem tem as condições de enfrentá-lo e permanece íntegro frente às ameaças de sua existência, vencendo sua impossibilidade física através da razão. O homem moral é o que permanece livre mesmo estando limitado fisicamente, é o que pode experimentar o Sublime.

Já o Sublime teórico é alcançado quando as condições do homem em relação ao conhecimento são ameaçadas: "Um objeto é sublime de modo teórico na medida em que traz consigo a representação da infinitude, para cuja apresentação à faculdade da imaginação não se sente a altura." (SCHILLER, 2011, p. 25)

Essas são as diferenças entre estes dois tipos de Sublime, aquele que coloca em confronto com as condições da existência física, e aquele que impossibilita a representação do objeto perante a imaginação. "Um exemplo do primeiro é o oceano em calmaria, o oceano em tempestade é um exemplo do segundo." (SCHILLER, 2011, p. 25). Esses dois temas são muito comuns durante o romantismo, a tempestade como exemplo do poder avassalador da natureza e o mar em calmaria como objeto de contemplação e do sentimento de ser permeado por Deus. A seguir, a figura 7 e 8 retratam esses exemplos:

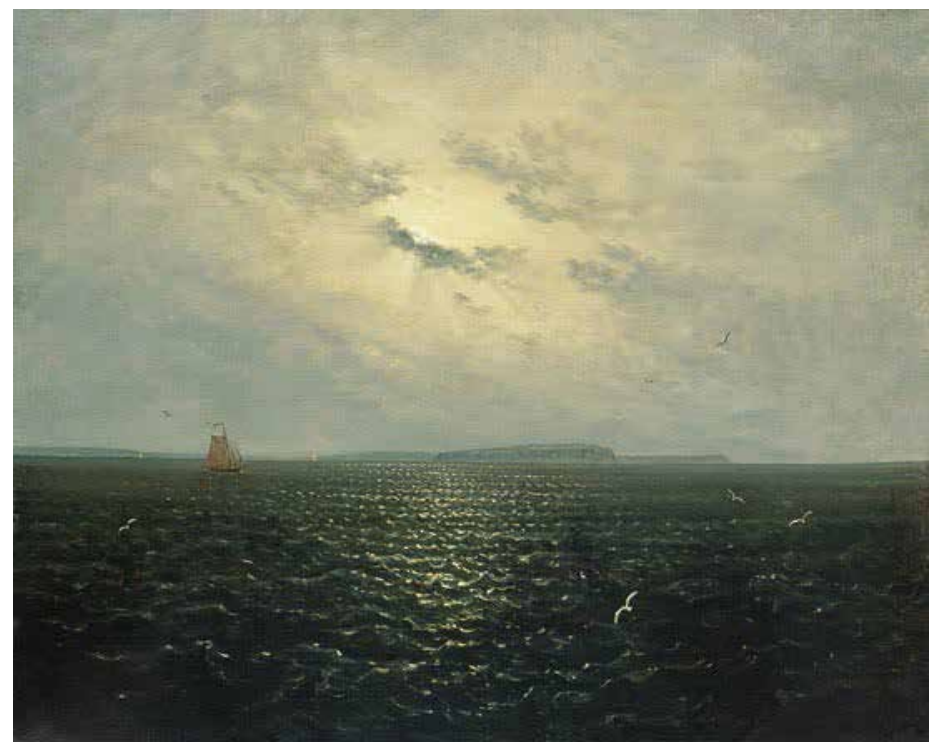

Fig. 7 - Carl Carus, Noite de luar perto de Rügen, 1819. óleo sobre tela, 71,5x53,5 cm; Hamburger Kunsthalle, Hamburgo. Fonte: (WOLF, romantismo, 2008). 


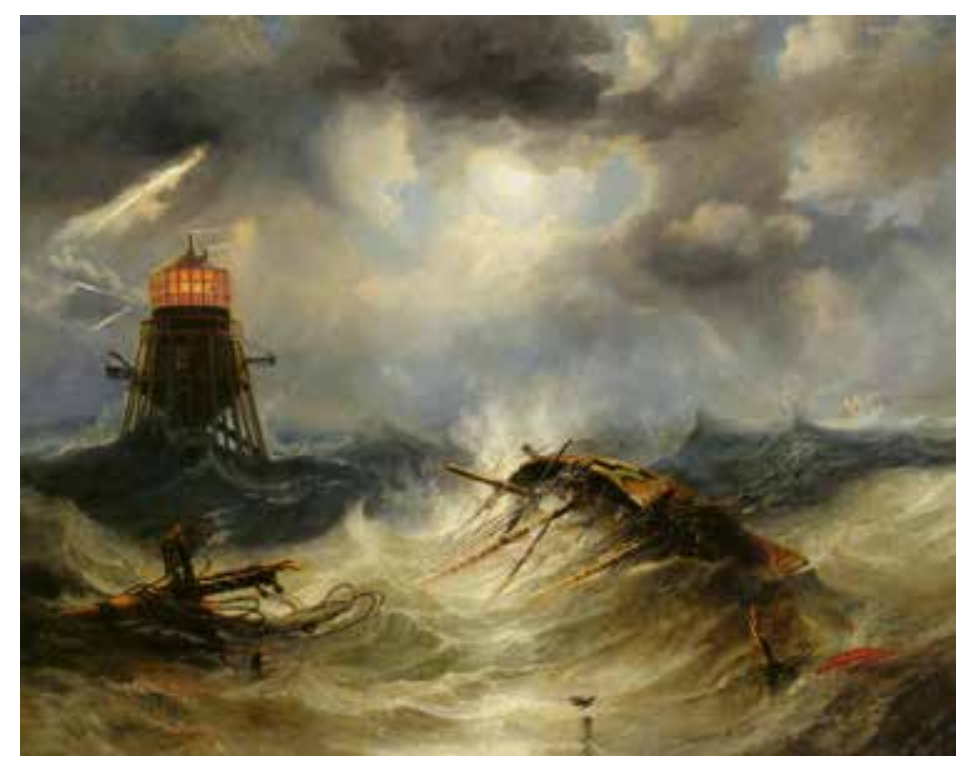

Fig. 8 - John Wilson Carmichael, O Farol de Irwin, tempestade furiosa, 1851. Óleo sobre tela, 81 x $100 \mathrm{~cm}$; Coleção privada.

Fonte: www.wikiart.org

Quando o homem é incapaz de chegar a uma representação de um objeto, quando é ameaçada a sua capacidade de conhecimento, apenas gera desprazer, entretanto quando a existência é ameaçada, desperta "dor na sensação imediata, desperta terror na representação;" (SCHILLER, 2011, p. 27)

Assim, o objeto terrível impressiona mais o espírito, a superação moral e a liberdade da razão são sentidas de forma mais vivaz. "Mas, precisamente por isso, porque o objeto temível ataca a nossa natureza sensível com mais violência do que o objeto infinito, (...)" (SCHILLER, 2011, p. 26).

Como o Sublime depende da consciência da superioridade racional é justamente o Sublime prático que o possibilita de forma mais intensa e acentuada, é neste Sublime que o homem põe à prova a sua capacidade de liberdade e autonomia perante a sua parte sensível.

Esta abordagem de Schiller torna o Sublime não apenas uma forma de estética na arte, mas também um importante tratado de filosofia, que investiga e averigua as capacidades morais no homem. É uma forma de explorar as capacidades inerentes do homem, com as quais ele se diferencia dos animais e o torna humano.

\footnotetext{
"O poder irresistível da natureza", afirma Kant, "nos faz, considerados como seres sensíveis, reconhecer a nossa impotência, mas descobre também em nós uma faculdade de ajuizar-nos como independentes dela, e uma superioridade em relação à natureza sobre a qual se funda uma autoconservação de tipo totalmente diferente daquela que pode ser constatada e colocada em perigo pela natureza fora de nós (...) Desse modo", prossegue ele, “o poder temível da natureza será esteticamente ajuizado por nós como sublime porque ele convoca aquela força em nós que não é natureza a ver como pequeno tudo aquilo pelo que estamos preocupados enquanto seres sensíveis. (SCHILLER, 2001, p. 28)
}

O Sublime pertence a um sentimento estético, e é dependente de percepções antes físicas, logo em seguida uma impressão individual anímica, ou seja, sentimentos que surgem a partir do que foi contemplado, por fim reconhecer nesse objeto de 
contemplação uma causa superior, um significado profundo além do ser humano. Por isso, quando se trata da força física da natureza humana dominando a natureza a fim de colocá-la a seu serviço, não traz essa elevação necessária, não produz sentimentos ligados à liberdade do homem sobre as forças naturais, o Sublime exige uma participação interna do homem, no âmbito da alma.

Quando a força natural supera fisicamente o homem, aí se inicia o processo de perceber a possibilidade da liberdade, não no aspecto físico e sim, da razão, mas para isso se faz necessário uma liberdade interna no homem para que possa conceber este estado de independência frente a natureza.

A questão de Schiller está sempre ligada à dualidade da natureza do homem, a uma parte dependente da natureza e outra ao aspecto livre dentro de sua individualidade. Os princípios do homem pertencem ao seu aspecto de liberdade e autonomia moral, o que o homem escolheu para tomar como princípio não pode ser tirado a não ser por sua própria escolha, é uma esfera de total liberdade, nenhuma ameaça a sua existência pode privá-lo disso.

O Sublime de Schiller é superação moral, aquilo que faz o homem transformar-se transpondo situações que põem a sua natureza física à mercê de forças que não pode controlar, mas possibilite enfrentar o temor através de sua autonomia moral e superá-lo.

De natureza poética Schiller representa de forma bela a essência do Sublime. A transformação através de um sofrimento, a superação através da consciência de uma inferioridade frente a forças superiores. Trata-se aqui de uma qualidade de conquistar uma elevação, mesmo sendo apenas na ideia, através da superação da dor:

Grande é aquele que sobrepuja o temível. Sublime é aquele que, mesmo sucumbindo, não teme.

Aníbal foi grande de modo teórico porque abriu uma passagem através dos Alpes intransitáveis até a Itália; grande de modo prático ou sublime ele só foi na infelicidade.

Hércules foi grande porque empreendeu os seus doze trabalhos e os concluiu.

Sublime foi Prometeu, porque acorrentado ao Cáucaso não se arrependeu de seu ato e não admitiu seu erro.

Grande podemos nos mostrar na felicidade, sublimes apenas na infelicidade. (SCHILLER, 2011, p. 39)

Esta concepção da vida em que é necessário vivenciar o trágico, o lastimável, o infortúnio, é próprio do homem romântico, que em meio a um desenrolar histórico confuso e revolucionário deparou-se com as decepções de seus sonhos e seus ideais.

Schiller determina três aspectos de representação do Sublime:

O Sublime é, desse modo, o efeito de três representações consecutivas: I. a representação de um poder físico objetivo; II. A representação de nossa impotência física subjetiva; III. A representação de nossa supremacia moral subjetiva. (SCHILLER, p 40)

Em "Sobre o Sublime" (1793), texto publicado em Escritos menores em prosa, Schiller continua abordando o Sublime com sua preocupação com o homem moral, destaca que o sentimento do Sublime é capaz de dar autonomia ao espírito indepen- 
dente das percepções sensíveis, ele torna o homem consciente de sua independência das leis da natureza:

O sentimento do sublime é um sentimento misto. Ele consiste numa junção de um estado de dor, que se exprime no seu grau máximo como um horror, com um estado de alegria, que pode se intensificar até o encantamento e que, embora não seja propriamente um prazer, é preferido por almas refinadas a todo prazer. Essa ligação de duas sensações contraditórias num único sentimento comprova nossa autonomia moral de maneira irrefutável. (SCHILLER, 2011, p. 60)

Não muito diferente de seus conterrâneos, Immanuel Kant, inspirador das ideias de Schiller, também descreve o sentimento do Sublime como uma elevação do homem moral frente a um poder imensamente maior que a sua capacidade física e imaginativa podem conter, essa elevação traz uma forma de meditação devocional perante essa grandiosidade da natureza. De forma apaixonada e de grande veneração, os poetas e artistas românticos costumam descrever os fenômenos colossais da natureza.

Rochedos arrojados, impendantes, quase ameaçadores, nuvens tempestuosas que torreiam no céu e se apressam com raios e trovões, vulcões em toda a sua violência destrutiva, furacões que deixam atrás de si a desolação, o oceano enfurecido e sem limites, uma alta cachoeira de um rio poderoso, e assim por diante, reduzem nossa capacidade de resistir, em comparação com a sua potência, a uma insignificante pequenez. Porém quanto mais temível, mais atraente é sua visão desde que estejamos seguros; e de bom grado dizemos que tais objetos são sublime, pois elevam a força do espirito de sua habitual mediocridade e nos fazem descobrir uma capacidade de resistência de espécie totalmente diversa, encorajando-nos a defrontar a aparente onipotência da natureza.(KANT apud ECO, 2004, p. 295)

A experiência do Sublime no romantismo não se trata apenas de observar o mundo, mas sim da relação do homem com o mundo, como o homem o percebe, como interage e o que tira daquela experiência e a que essa experiência o leva.

A experiência do Sublime está em um profundo ato de autoconhecimento, de uma consciência própria, de percepção como um ser individual, dotado de uma razão e uma gama de sentimentos. Em conjunto a esse ato de conhecer-se está o ato de desprender-se de si mesmo, um ímpeto da alma em lançar-se para um significado mais profundo por detrás de todas as coisas, algo além do homem, e esse elemento pode ser chamado de algo espiritual.

A percepção do espiritual não está apenas no mundo circundante, mas também na consciência de ser parte desse espiritual, possuí-lo dentro de si. No romantismo, estes dois elementos, ou seja, a impressão individual que surge a partir da observação do mundo e o reconhecimento de algo que supera sua individualidade e que permeia de forma onipresente toda a natureza, estão fortemente ligados quando se trata de uma experiência do Sublime na natureza ou na arte. Assim, a experiência do Sublime trata-se de alguma maneira de compreender e aceitar profundamente o seu tamanho, e encontrar o seu lugar diante da imensa potência da natureza.

A introspecção e o olhar para si mesmo são uma forma de tentar compreender o mundo, de voltar a conectar-se com a natureza, sentir-se parte dela. Isso também acontece de maneira inversa, ao olhar para a natureza e deparar-se com as profundas 
forças que a regem, o homem romântico busca encontrar a si mesmo, tenta olhar para o seu próprio ser.

Na obra de arte o homem romântico encontra uma maneira de concretizar, de manter presente esse momento, como forma de compreendê-lo profundamente, e de poder vivenciá-lo novamente através da interação da obra de arte.

Para o homem romântico o sublime é um sentimento estético essencial, ainda mais do que trazer a interiorização própria do romantismo, leva ao homem a um movimento interno participativo em conjunto com as forças da natureza a fim de chegar a esse estado, e a arte não poderia deixar de fazer o mesmo papel: "Em todos estes casos, mais que representar a natureza em um momento Sublime, a pintura busca apresentar (com a nossa colaboração) a nossa experiência do sentimento do Sublime." (ECO, 2004, p. 296)

\section{Estética do grotesco}

Kayser chama a atenção para o termo Grotesco. Por ter sido muitas vezes usado no mesmo sentido de arabesco, este último tendo um significado ligado à ornamentação. É a través dos escritos de Friedrich Schlegel [Conversação sobre a poesia, 1800] que se inicia a separação mais definida entre esses dois termos.

Kayser considera Schlegel como um importante teórico de estética do início do romantismo, assim chega ao conceito através dos fragmentos da Conversação sobre a Poesia de Schlegel. Portanto, assim como o Sublime, inicialmente o termo Grotesco estava relacionado a termos literários:

\footnotetext{
Grotesco - assim rezam os Fragmentos 75, 305, 389 - é o contraste pronunciado entre forma e matéria (assunto), a mistura centrifuga do heterogêneo, a força explosiva do paradoxal, que são ridículos e horripilantes ao mesmo tempo. Como na estética do século XVIII, os conceitos de caricatura, mas também os do trágico e do cómico, penetram agora nos enunciados: "A caricatura é uma vinculação passiva do ingênuo e do grotesco. O poeta pode empregá-la tanto trágica como comicamente" (N. $\left.{ }^{\circ} 396\right)$. (KAYSER, 1986, p. $56-57$ )
}

Não foi apenas Schlegel que deu atenção a este tema no romantismo, mas de forma geral considerou-se inicialmente o Grotesco como uma sátira, ou humor satânico conforme o escritor alemão Jean Paul.

O romantismo foi terreno fértil para esta abordagem da estética, visto que a descrença no ser humano e a desilusão reinavam na alma do homem. A sátira, entretanto, é uma forma de provocação, um chamado a transformação através de uma forma de humor. "Por trás da cópia negativa da sátira, sente-se a imagem positiva como uma possibilidade no homem". (KAYSER, 1986, p. 62)

A sátira, como ideia do Grotesco, arranca do mundo suas máscaras, deixa à mostra as feridas e zomba delas. Nas palavras de Goethe "Vista das alturas da razão, toda a vida parece uma enfermidade maligna, e o mundo um manicômio". (GOETHE apud KAYSER, 1986, p. 62) São as debilidades do homem e suas paixões baixas que são vistas agora como pertencentes a sua natureza. Não é ao acaso que aparece na literatura do romantismo a figura do diabo, que seduz e tenta o homem com aquilo que ele mais deseja. Ceder às tentações do diabo não tem preço menor que a própria alma do homem. 
As representações de figuras humanas com partes de animais, cabeça, pé, etc., não são mais do que metaforicamente se referir ao declínio humano a seu estado bestial.

Como dramaturgo e poeta Victor Hugo interessou-se na estética do Sublime e com seu oposto, o Grotesco. Como meditação do seu próximo livro a ser publicado sob o nome Cromwell, Victor Hugo discorre em seu prefácio [Do Grotesco e do Sublime] sobre estas ideias, de uma forma crítica e propondo uma poesia nova, desvinculada os modelos do passado.

Victor Hugo luta por uma nova forma de arte, e aponta para um novo elemento inserido na arte romântica, "(...) eis uma nova forma que se desenvolve na arte. Este tipo, é o Grotesco. Esta forma, é a comédia" (HUGO, 1988, p. 26). Victor Hugo não se desvincula da ideia do Grotesco como sátira, a comédia é uma forma de trazer à luz o que está oculto nas sombras.

Esta é então a cisão da nova poesia, da poesia clássica. A comédia representa o Grotesco inserido na literatura.

Victor Hugo dá valor ao Grotesco pelas possibilidades que este representa na arte, ao fugir dos modelos antigos e buscando inspiração na natureza encontra uma fonte inesgotável de possibilidades: "(...) Voltemos pois, e tentemos fazer ver que é da fecunda união do tipo grotesco com o tipo sublime que nasce o gênio moderno, tão complexo, tão variado nas suas formas, tão inesgotável nas suas criações, (...)" (HUGO, 1988, p. 27)

Para também dar mérito à arte antiga, o escritor coloca que o Grotesco de alguma forma já estava presente na antiguidade, mas é no romantismo que ele vem a ocupar o seu papel, amadurece e se torna próprio do seu tempo:

Não que fosse verdade dizer que a comédia e o grotesco eram absolutamente desconhecidos entre os antigos. A coisa aliás seria impossível. Nada vem sem raiz; a segunda época está sempre em germe na primeira. Desde a Ilíada, Tersites e Vulcano, oferecem a comédia, um aos homens, o outro aos deuses. (...) Os tritões, os sátiros, os cíclopes, são grotescos, as sereias, as fúrias, as parcas, as harpias, são grotescas; Polifemo é um grotesco terrível; Sileno é um grotesco bufo". (HUGO, 1988, p. 27 - 28ᄀ)

Hugo relaciona o Grotesco não somente com a forma dos objetos, mas antes com a qualidade das mesmas, a natureza horrível e cômica por detrás da forma:

(...) O grotesco antigo é tímido, e procura sempre esconder-se. Sente-se que não esta no seu terreno, porque não esta na sua natureza. (...) Os sátiros, os tritões, as sereias são apenas disformes. As parcas, as harpias são antes horrendas por seus atributos que por seus traços, isto é, doces, benfazejas. Há um véu de grandeza ou divindade sobre outros grotescos. Polifemo é gigante; Midas é rei, Sileno é deus. (HUGO, 1988, p. 28)

A imensa capacidade que o Grotesco pode dar à arte incita ao artista romântico a utilizá-lo de forma abrangente, é a importância que se dá à criatividade, à criação do fantástico, do obscuro, do que está fora da normalidade:

No pensamento dos modernos, ao contrário, o grotesco tem um papel imenso. Aí 
esta por toda parte, de um lado, cria o disforme, e o horrível; do outro, o cômico é o bufo. Põe ao redor da religião mil superstições originais, ao redor da poesia mil imaginações pitorescas. É ele que semeia, as mancheias, no ar, na água, na terra, no fogo, estas miríades de seres intermediários que encontramos bem vivos nas tradições populares da Idade Média; é ele que faz girar na sombra a ronda pavorosa do sabá, ele ainda que dá a Satã os cornos, os pés de bode, as asas de morcego. É ele, sempre, que ora lança no inferno cristão estas horrendas figuras que evocará o áspero gênio de Dante e de Milton, (...) Se passa do mundo ideal ao mundo real, aqui desenvolve inesgotáveis paródias da humanidade. (HUGO, 1988 , p. 28 - 29)

$\mathrm{Na}$ antiguidade o Grotesco é visto como algo a se esconder, a se envergonhar; no romantismo se quer pôr à mostra, retirá-lo das sombras, satirizar, "transforma os gigantes em anões; dos ciclopes faz os gnomos." (HUGO, 1988, p. 30)

Mas antes de ser uma criação da imaginação o Grotesco está presente na natureza, assim como a beleza faz parte da polaridade que é inerente a ela. "Somente diremos aqui que, como objetivo junto do sublime, como meio de contraste, o grotesco é, segundo nossa opinião, a mais rica fonte que a natureza pode abrir à arte." (HUGO, 1988, p. 31)

O Grotesco surge para criar o contraste, movimentar a arte, porém não exclui o belo nem o Sublime e sim possibilita que estes se mostrem de maneira mais vivaz e intensa. Assim, Hugo define o Grotesco, sem poder deixar de definir juntamente o Sublime como uma polaridade que o completa:

Com efeito, na poesia nova, enquanto o sublime representara a alma tal qual ela é, purificada pela moral cristã, ele representara o papel da besta humana. O primeiro tipo livre de toda mescla impura, terá como apanágio todos os encantos, todas as graças, todas as belezas; é preciso que possa criar um dia Julieta, Desdémona, Ofélia. O segundo tomará todos os ridículos, todas as enfermidades, todas as feiuras. Nesta partilha da humanidade e da criação, é a ele que caberão as paixões, os vícios, os crimes; é ele que será luxurioso, rastejante, guloso, avaro, pérfido, enredador, hipócrita; é ele que será alternadamente Iago, tartufo, Basílio; Polônio, Harpagão, Bartolo; Falstaff, Scapino, Fígaro. (HUGO, 1988, p. 33)

$\mathrm{Na}$ arte que ele chama de moderna, estão sempre presentes estes dois tipos de maneira a se contrastarem. Como um romântico, Hugo dá ênfase às polaridades, o Sublime ao que concerne a divindade, e ao que ele chama de Grotesco cabe aquilo que o homem tem de mais baixo, a sua sombra, o seu lado animal, e justamente por isso ele se encontra em toda parte. O feio, como oposto do belo é aquilo que não está em harmonia, não se mostra na sua totalidade, e por isso aparece em aspectos fragmentados, pois está incompleto, se mostra das mais variadas formas, e sempre há possibilidades de descobrir novos aspectos.

Hugo descreve as formas em que o Grotesco imprime suas qualidades. Na época do romantismo, ele invade os contos, as fábulas, os romances e a arte, faz referência ao Grotesco presente ao que foi chamado de pitoresco:

Imprime sobretudo seu caráter a esta maravilhosa arquitetura que, na Idade Média, ocupa o lugar de todas as artes. Prende seu estigma na fachada das catedrais, emoldura seus infernos e seus purgatórios sob a ogiva dos portais, fá-los flamejar nos vitrais, desenrola seus monstros, seus cães de fila, seus demônios ao redor dos 
capiteis, ao longo dos frisos, nas bordas dos telhados. (...) Das artes, passa para os costumes; e enquanto faz que o povo aplauda os graciosos da comédia dá aos reis os bobos da corte. (HUGO, 1988, p. 34 - 35)

Invadindo a arte romântica em todos os seus aspectos, inclusive na vida cotidiana do povo, o Grotesco alavanca um olhar do homem para si mesmo, reconhece a sua dupla natureza: a que é pura e imaculada, e a que é fadada a erros e vícios, mas é isto que faz o homem transformar-se, justamente o caminho que se trava entre essas polaridades.

Sobretudo, Hugo ressalta o período romântico como momento fértil para o desenvolvimento desta estética, enfatizando a qualidade dos românticos de fazerem surgir esta aliança entre o sublime e o grotesco, ou o belo e o feio de maneira genuína. "A antiguidade não teria feito a Bela e a Fera." (HUGO, 1988, p. 36).

Em a Bela e a Fera, 1740, de Gabrielle-Suzanne Barbot, encontra-se de forma implícita essa genuína contradição da relação que pode nascer entre esses extremos tão distantes, mas ao mesmo tempo tão íntimos e complementares. $O$ amor que passa a nascer na jovem donzela acontece graças a uma superação interna de apenas enxergar a aparência. $O$ amor nasce quando se consegue ver dentro de uma fera horrível um coração bom, a feiura de certa forma torna-se bela. A capacidade de conectar esta contradição, de dar um sentido oculto torna o Grotesco uma forma de beleza.

O romantismo reverte a condição humana, deixando na arte transparecer a natureza selvagem do homem, o seu âmbito dos instintos, dos vícios, dos horrores que se escondem no recanto mais sombrio do seu ser. A sua natureza superior, a sua alma, fica resguardada, escondida dentro de si para um dia ser descoberta, resgatada. É necessário aceitar o Grotesco para se chegar ao Sublime.

Mas mesmo com essa união entre o Sublime e o Grotesco, Hugo coloca o Grotesco como predominante na arte romântica, principalmente na literatura. E enfatiza acima de tudo que isto deve ser passageiro, pois para chegar à excelência deve existir o equilíbrio entre estes dois princípios. “Um homem, um poeta-rei, poeta soberano, como Dante o diz de Homero, vai tudo fixar. Os dois gênios rivais unem sua dupla chama, e desta chama brota Shakespeare." (HUGO, 1988, p. 36)

Finalmente, Hugo descreve o que considera a excelência da arte romântica, a forma de arte que é capaz de representar o homem da sua época, o qual está consciente da sua dupla natureza, esta forma é o drama:

Ei-nos chegando à sumidade poética dos tempos modernos. Shakespeare, é o drama; e o drama, que funde sob um mesmo alento o grotesco e o sublime, o terrível e o bufo, a tragédia e a comédia, o drama é o caráter próprio da terceira época da poesia, da literatura atual. (HUGO, 1988, p. 36 - 37)

Como antecessores de Shakespeare estão Milton e Dante, pois suas obras trazem essa união do Sublime e do Grotesco, satirizam de certa forma o homem, Dante com a sua Divina Comédia (1555) e Milton com o Paraíso Perdido (1667). O inferno, o anjo caído, as imagens grotescas de seres demoníacos, todas estas imagens inspiram os artistas e o fazem perceber sua natureza dual: 


\begin{abstract}
Do dia em que o cristianismo disse ao homem: "Você é duplo, você é composto de dois seres, um perecível, o outro imortal; um carnal, o outro etéreo; um, prisioneiro dos apetites, necessidade e paixões, o outro levado pelas asas do entusiasmo e da fantasia: aquele, enfim, sempre curvado para a terra, sua mãe, este outro lançado sem cessar para o céu, sua pátria"; desde este dia foi criado o drama. (HUGO, 1988, p. 42)
\end{abstract}

Observam-se em Hugo os traços comuns que percorrem o pensamento romântico. Nessas ideias está presente uma postura religiosa ainda ligada ao cristianismo, porém consciente da representação da divindade como natureza. É dela que se deve seguir os modelos para a arte e nela também se encontra a dualidade, a qual está inserida dentro do homem como pertencente também à natureza. Nesta dualidade o homem mostra a sua face terrível, monstruosa e perversa e como oposição o seu Eu espiritual, o aspecto da beleza, ou talvez do Sublime, como o próprio Hugo o coloca. Essa característica de dualidade própria do romantismo coloca o homem em uma constante luta interior, em um constante conflito entre sentimentos opostos. Aceitar essa condição e sobrepor-se a elas entendendo-as como qualidades complementares e necessárias para o desenvolvimento do ser humano, isto é o drama, esta é a nova poesia que exprime de maneira direta a própria constituição humana, retrata a verdade neste sentido mais interior.

O feio, o disforme faz o homem retroceder, renegá-lo porque fala dele mesmo, e às vezes a verdade assusta e não se quer aceitar. $O$ homem romântico está debruçado sobre si mesmo, explorando todos os sentimentos que dele podem brotar. Assim, quando se depara com a sua sombra, as satiriza, zomba dela de forma a aceita-la. Assim nasce a comédia. Cabe ao homem conviver com sua dupla natureza e perceber as possibilidades que surgem através dela. "Agora a Beleza pode se exprimir fazendo convergir os opostos: O Feio já não é a negação, mas a outra face do Belo." (ECO, 2004, p. 321)

A condição de renegar o feio passa a ser apenas uma primeira impressão, a aparência do Grotesco pode levar ao asco, ao medo, ao horror. Entretanto, essa falsa condição do feio está na sua forma, o homem romântico transpassa essa impressão sensorial e mergulha profundamente no que se esconde por detrás das aparências. Disso nasce algo significativo, percebe-se uma natureza distinta que pode ser bela e que pode levar ao Sublime.

Quando se percebe isto, não apenas no mundo exterior, mas dentro de si mesmo, o homem dá-se conta que é necessário conviver com o seu aspecto de sombra, com o seu duplo, pois essa percepção possibilita a sua transformação.

Porque os homens de gênio, por grandes que sejam, tem sempre sua fera que parodia sua inteligência. (...) "do sublime ao ridículo há apenas um passo", dizia Napoleão, quando se convenceu de que era homem; este relâmpago de uma alma de fogo que se entreabre, ilumina ao mesmo tempo a arte e a história, este grito de angustia é o resumo do drama da vida. (HUGO, 1988, p. 44 - 45)

Victor Hugo não apenas teorizou o Sublime e o Grotesco, mas aplicou estes dois princípios no decorrer de suas obras, considerando que é necessário percorrer 
por estas polaridades para se chegar ao êxtase e ao deleite que o Sublime proporciona. Deparar-se com sua própria imagem representada pelas figuras monstruosas e disformes faz o homem reconhecer-se e possibilita a sua transformação. Assim como Eco discorre:

É Hugo, teórico do grotesco como antintese do Sublime e novidade da arte romântica, que cria uma galeria inesquecível de personagens grotescos e repugnantes, do corcunda Quasímodo ao rosto disforme do homem que ri, até as mulheres devastadas pela miséria e pela crueldade da vida, que parecem ter ódio da Beleza terna das crianças inocentes. (ECO, 2004, p. 322)

O Corcunda de Notre-Dame (1831), de Hugo ilustra justamente esse conflito humano de aceitar que do feio possa brotar a beleza. Esta beleza está relacionada com a própria natureza interna do homem. Como representado na figura 9, o Quasímodo é disforme, grotesco e causa horror, entretanto possui uma alma gentil e doce. O drama da vida é essa batalha, essa aparente contradição da condição humana. Enxergar o Grotesco na natureza é uma ação quase que inconsciente de dar-se conta que o próprio homem carrega o Grotesco em si mesmo.

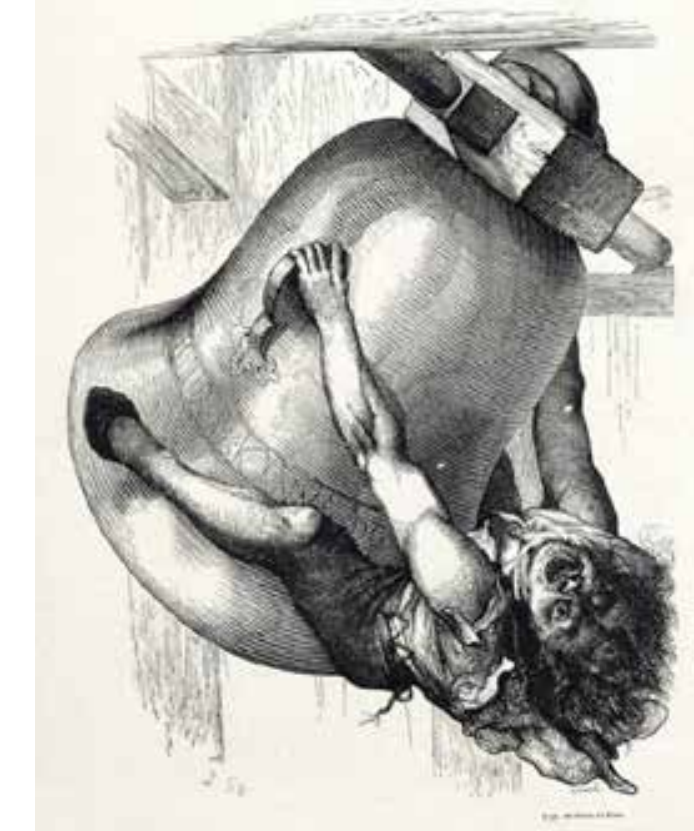

Fig. 9 - Louis Charles Steinheil, Quasimodo tocando o sino, 1844. Gravura de Laisné. Fonte: www.philitt.fr

Muitas das qualidades que definem o Grotesco estão também inseridas em alguns dos elementos que pertencem ao Sublime. Estas naturezas incialmente opostas se cruzam em muitos aspectos.

Uma destas qualidades, como é perfeitamente perceptível, é a escuridão, o obscuro. $\mathrm{O}$ Grotesco além de cômico, também causa horror. Na imagem 10, vê-se Dante e Virgílio no inferno, que como descrito na obra de Dante Alighieri não é nada agradável, e muitas vezes o herói desta jornada se sente obrigado a desviar o olhar, e a temer a horrível cena que está diante dele. Para criar esta atmosfera do terrivel, a obscuridade se torna extremamente propícia. Desta maneira, "Para tornar algo extremamente terrivel, a obscuridade parece ser, em geral, necessária." (BURKE, 1993, p. 66). 
Burke utiliza esse atributo para se referir ao Sublime, mas como se vê no Grotesco, é essencial que se tenha uma obscuridade para tornar o objeto ainda mais caracterizado. Parece ser da própria natureza do Grotesco viver nesse âmbito da escuridão.

Qualquer pessoa poderá perceber isso, se refletir o quão intensamente a noite contribui para o nosso temor em todos os casos de perigo e o quanto as crenças em fantasmas e duendes, dos quais ninguém pode formar idéias precisas, afetam os espíritos que dão crédito aos contos populares sobre tais espécies de seres. (BURKE, 1993, p. 66 - 67)

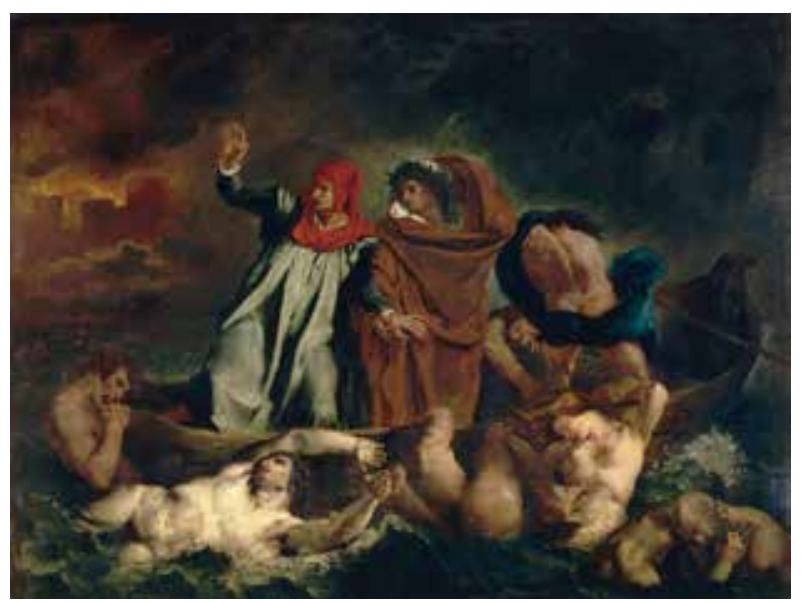

Fig. 10 - Eugene Delacroix, A Barca de Dante (Dante e Virgílio no Inferno), 1822. óleo sobre tela, $189 \times 241,5 \mathrm{~cm}$;

Museu do Louvre, Paris, França. Fonte: www.wikiart.org

É na noite em que se abrem as portas para o fantástico, com a noite o homem mergulha no seu inconsciente, naquilo que é mais profundo e obscuro na sua consciência, aonde podem brotar seus temores, seus medos, e deparar-se com sua natureza bestial. Com a noite vêm os sonhos, e com eles as possibilidades do imaginativo, do fantástico. Aqui, eles encontram sua própria morada, nascem assim os seres fantasmagóricos, terríveis (o diabo, as bruxas, etc.).

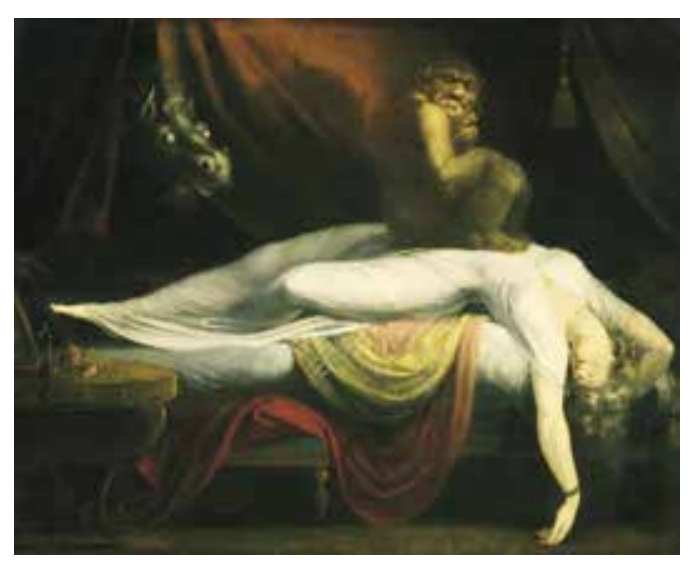

Fig. 11 - Henry Fuseli, O pesadelo, 1781. óleo sobre tela, $127 \times 102 \mathrm{~cm}$;

Detroit Institute of the Arts.Fonte: www.wikiart.org

Na figura 11, a figura feminina adormecida está extremamente contorcida e distorcida, para retratar a tensão e a agonia que a presença do horrível gnomo sobre seu peito causa. Da escuridão atrás das cortinas surge uma cabeça fantasmagórica 
de um cavalo, de olhos brancos e arregalados, que causam pavor. Os sonhos e pesadelos são representações do inconsciente, neste âmbito as criaturas do Grotesco se expressam de maneira completa.

O Grotesco está naquilo que não é habitual, o que não é familiar na sua aparência à natureza do homem. O que é disforme, o que é excêntrico, causa horror porque não é conhecido, não é a normalidade.

Como já mencionado, o Grotesco repudia, causa estranhamento, entretanto há algo na natureza do homem que se sente atraído por cenas macabras, pelo mistério e pelo desconhecido. "É um fenômeno generalizado em nossa natureza que aquilo que é triste, terrível e até mesmo horrendo atrai com irresistível fascínio; que cenas de dor e terror nos repugnem e, com igual força, nos atraiam" (SCHILLER apud ECO, 2004, p. 289). É tão intensa essa tentação que não foi à toa que no romantismo as histórias dessa natureza começaram a fascinar os poetas e a descrição detalhada minuciosa mostra esse interesse. Na obra plástica, a fantástica natureza do Grotesco prende o olhar de maneira intensa. O homem se deixa levar pelos inúmeros detalhes das repugnantes criaturas ou da misteriosa cena que se mostra entre véus de escuridão, tentando desvendar com sua imaginação o que se encontra escondido ali.

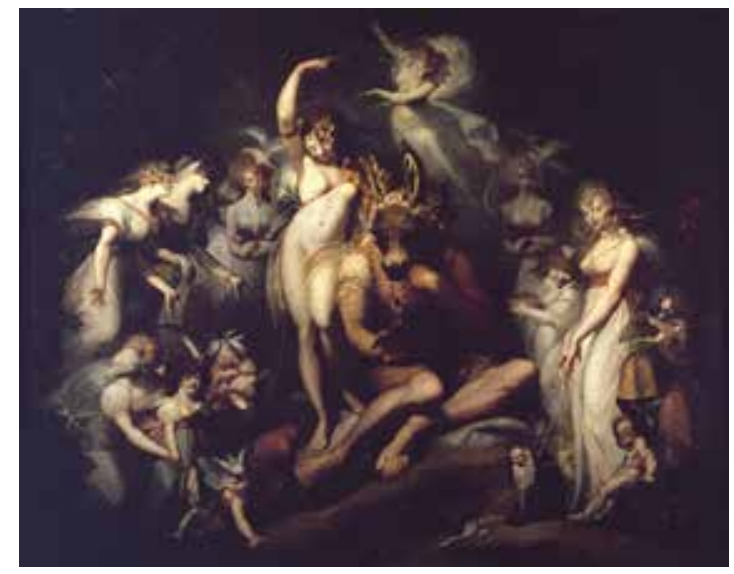

Fig. 12 - Henry Fuseli, Titânia e Bottom, 1790. óleo sobre tela, $217,2 \times 275,6 \mathrm{~cm}$;

United Kingdom

Fonte: www.wikiart.org

A figura 12 de Henry Fuseli retrata uma cena da peça de Shakespeare, Sonho de uma Noite de Verão (1590). A cena mostra a punição da rainha Titânia, a qual foi enfeitiçada e acabou apaixonando-se por Bottom, cuja cabeça foi transformada em um burro. A cena é carregada por obscuridade, e os personagens são iluminados suavemente, as vezes parcialmente, apenas para que fiquem à mostra, entretanto há criaturas que ainda permanecem nas sombras. Nos detalhes percebem-se seres um tanto sinistros, diabólicos.

A paixão da dama por uma criatura horrenda é novamente retratada, a beleza e o celestial que se relacionam com a matéria, com o monstruoso. Entretanto, por detrás do feitiço que transformou a cabeça de Bottom em burro, ainda permanece uma alma humana. Esta transformação representa o ser humano que cedeu aos seus desejos e vícios.

Outro elemento aonde se encontra o Grotesco é a morte. A morte do herói 
romântico é exaltada, enaltecida e aclamada: "para o homem romântico mesmo a morte, arrancada ao reino do macabro, tem a sua fascinação e pode ser bela" (ECO, 2004, p. 307). Mais que Grotesca e trágica, a morte passa a ser bela, uma forma de liberdade em direção à divindade, a união com a natureza, uma aceitação do seu destino:

(...) por trás da bela morte há mortes lânguidas de Lindo e Clorinda em Jerusalém libertada, por trás do satanismo, que bem ou mal significa a humanização de Satanás, está o olhar triste que Marino atribuíra ao príncipe dos infernos em A matança dos inocentes e, sobretudo, o Satanás de Milton, exaltado por boa parte da literatura romântica, que não perde, apesar da queda, a sua cintilante Beleza. (ECO, 2004, p 323)

Não só a morte é reverenciada, mas tudo ao que ela se atribui "mas belos também são os túmulos, noturnos ou não" (ECO, 2004, p. 323). Os cemitérios, o crucifixo e todas as criaturas que percorrem esse cenário da morte são altamente utilizadas por tudo o que envolve a arte romântica. O horror, o repugnante, o macabro são uma forma de beleza.

O romântico mergulha impetuosamente no seu 'duplo' - como, aliás, em tudo o que é obscuro e ambíguo, caótico e beatífico, demoníaco e dionisíaco - e busca nisso apenas um refúgio contra a realidade que é incapaz de dominar por meios racionais. Nesta fuga da realidade descobre o inconsciente, aquilo que está oculto, em segurança contra o espirito racional, a fonte dos sonhos de realização dos seus anseios e das soluções irracionais dos seus problemas. (HAUSER, 1982, p.834)

O que Hauser aponta é outra questão do Grotesco. Não como uma questão de autoconhecimento consciente, da necessidade de querer entender o homem na sua plenitude, mas neste outro âmbito cumpre a função de escape. Como mais tarde viria a ser desenvolvido na psicanalise por Freud, o sonho como expressão dos desejos reprimidos.

\section{Correlações entre o sublime e o grotesco}

Os românticos - em particular Novalis e Friedrich Schlegel, animadores da revista Athenäum, e Hölderlin - não buscam uma beleza extática e harmônica, mas dinâmica, um devir, e portanto desarmonia na medida em que (como ensinava também Shakespeare e os maneiristas) o belo também pode brotar do feio, a forma do informe, e vice-versa. (ECO, 2004, p. 315)

Mesmo sendo apresentadas naturezas tão distintas e polares, o Sublime e o Grotesco pertencem a uma mesma forma de se relacionar com o mundo.

O homem romântico vive em uma esfera de luta, convive entre duas naturezas com as quais precisa lidar.

O Grotesco cria os chifres, os cascos do astuto Mefistófeles e faz com que o herói romântico se depare com o que há de mais animalesco em si, que olhe para sua sombra e veja que não é só constituído de beleza. 
Mas o Grotesco, além de incitar horror na primeira impressão, possibilita que o homem se transforme. "Sou parcela do além, força que cria o mal e também faz o bem!" (GOETHE, 2002, p. 59) Pelas palavras de Mefistófeles, Goethe exprime a ideia de que graças às peripécias causadas por Mefistófeles, no final faz com que Fausto se transforme. O mal necessário para criar o bem. Estas são as provações da vida, este é o drama.

Neste pensamento, o Grotesco é um caminho com o qual se chega ao Sublime, isto se o homem está disposto a mover-se interiormente, se está disposto a transformar-se de maneira livre.

No final, mesmo Fausto tendo cedido a todos os seus desejos e praticado os atos mais baixos que a sua natureza o permitiu, a sua alma é redimida no papel do doce Margarida. Alcançando o êxtase, o deleite da alma, o Sublime após ter se rendido as tentações do diabo.

A tentação de Mefistófeles é o Grotesco, e a compaixão de Margarida - como alma de Fausto - é o Sublime. A isto se chega ao que Schiller pretendia, o domínio moral acima do enorme poder da natureza, tornar-se livre dos instintos à medida que os reconhece e escolhe a qual a natureza servir.

No romantismo, estas duas expressões estéticas servem a um mesmo intuito. São formas de conhecer o homem, de olhar para a sua natureza interna. Por isso, a experiência destes sentimentos não se dá de maneira passiva, deve-se estar desperto para reconhecer dentro de si a natureza do Grotesco e a divindade que provém da natureza também presente dentro do homem.

Originais são, de fato, alguns aspectos particulares da Beleza romântica (...) Mas original é sobre tudo o laço entre as diversas formas, ditado não pela razão, mas pelo sentimento e pela razão, laço que não visa excluir as contradições ou resolver as antíteses (finito/infinito, inteiro/fragmento, vida/morte, mente/coração), mas acolhê-las em uma co-presença que constitui a verdadeira novidade do Romantismo. (ECO, 2002, p. 299)

Distanciar esses dois temas no romantismo se torna uma tarefa difícil ou talvez desnecessária, pois estão sempre presentes conjuntamente em menor ou maior escala. Para vivenciar as experiências que a natureza lhes oferece, os românticos as configuram inicialmente dentro de si mesmos, desta maneira a experiência de deleite que o Sublime proporciona é possível graças ao reconhecimento de um elemento humano inferior, animal. Ao mesmo tempo, ao relacionar-se com o Grotesco, o homem aspira uma transformação de seus elementos inferiores.

\section{Considerações finais}

Viu-se que no romantismo desenvolveram-se elementos propícios para a configuração desses elementos estéticos na arte. Mas, antes de expressar-se na arte trata-se de uma questão humana interior, por isso é tão intensa e abundante neste período cultural.

O Sublime é um sentimento de estar nu e indefeso frente à grandiosidade e perfeição da natureza. Ao vislumbrar o esplendor de forças divinas, o homem dá-se 
conta sua pequenez, de suas imperfeições, enxerga em si mesmo a sua sombra carregada de monstros. Por isso, o Sublime causa horror, espanto e medo, pois o homem é arremessado ao abismo, sente-se totalmente mergulhado em uma presença divina e ao mesmo tempo dá-se conta de sua dupla natureza. Assim, no processo meditativo da experiência do Sublime o Grotesco está presente, mesmo que de maneira indireta.

O Grotesco, ao contrário, ocupa todos os espaços, está por toda parte no romantismo. Revela-se nos sonhos, nos devaneios, nas fantasias e mergulha no imaginário de forma vivaz e convincente, pois é na vida diária que o Grotesco se apresenta, faz parte da sociedade e do homem.

Entretanto, não são apenas os monstros que fascinam, o homem romântico aspira por transformações e luta por mudanças. Por isso na arte ao apresentar o Grotesco se faz como provocação. Ao retratar o feio tem-se a esperança de uma tomada de consciência, de um despertar para transformações. Dante não apenas desceu ao inferno, mas também no final mereceu a entrada no paraíso. Todos os horrores presenciados no infortúnio são como provações para conquistar o Sublime.

Neste sentido o Sublime e o Grotesco no Romantismo estão unidos, são um caminho contínuo, presentes paralelamente dentro do homem. Em suma estas duas formas de estéticas são resultado de um anseio do homem religar-se a si mesmo, encontrar-se e descobrir-se. Assim, o Grotesco e o Sublime são ferramentas com as quais é possível olhar-se profundamente e ao mesmo tempo olhar para o mundo. $\dot{E}$ um duplo trabalho.

O drama da vida, como o diz Victor Hugo, é a junção do Sublime e do Grotesco, é o equilíbrio na arte, aonde através do Grotesco se vivência o Sublime.

O Sublime e Grotesco não são de maneira nenhuma estéticas desenvolvidas apenas neste período. Entretanto, no romantismo foram desenvolvidas desta maneira. Foi o meio que o homem romântico encontrou de expressar a forma com que via o mundo e a natureza do homem. Foi a maneira que se configurou um estado de alma a partir de processos históricos, culturais e sociais.

\section{Referências}

BARBAS, H. O Sublime e o Belo - de Longino a Edmund Burke. CENTRIA E

DEP/FCSH Universidade Nova Lisboa. Lisboa, Portugal, 2006.

BURKE, E. Uma investigação filosófica sobre a origem de nossas ideias do sublime e do belo. São Paulo: Papirus, 1993.

ECO, U. História da Beleza. Rio de Janeiro: Record, 2004.

GOETHE, J. W. Fausto. São Paulo: Nova Cultural, 2002.

GOETHE, J. W. Doutrina das cores. São Paulo: nova Alexandria, 1993.

GUINSBURG, J. O Romantismo. São Paulo: Perspectiva, 2011. 
HAUSER, A. História Social da Literatura e da Arte - Tomo II. São Paulo: Mestre Jou, 1982.

HUGO, V. Do Grotesco e do Sublime. 2. ed. São Paulo: Perspectiva, 2002.

KAYSER, W. O Grotesco. São Paulo: Perspectiva, 1986.

SCHILLER, F. Do Sublime ao Trágico. São Paulo: Autêntica, 2011.

VÁZQUEZ. A. S. Convite à Estética. Rio de janeiro: Civilização Brasileira, 1999.

WOLF, N. Romantismo. Taschen, 2008 